\title{
Evaluation of alkaline deconstruction processes for Brazilian new generation of eucalypt clones
}

\author{
Fernando José Borges Gomes ${ }^{\mathrm{a}, *}$, Jorge Luiz Colodette ${ }^{\mathrm{a}}$, Augusto Milanez ${ }^{\mathrm{b}}$, \\ José Carlos Del Río ${ }^{\mathrm{c}}$, Marcelo Coelho dos Santos Muguet ${ }^{\mathrm{d}}$, \\ Larisse Aparecida Ribas Batalha ${ }^{a}$, Adriana de Fátima Gomes Gouvêa ${ }^{e}$ \\ a Pulp and Paper Laboratory, DEF-UFV, Viçosa, Zip Code: 36.570-000, MG, Brazil \\ b Suzano Paper and Pulp Co., São Paulo, SP, Brazil \\ ${ }^{\mathrm{c}}$ CSIC-IRNAS, Seville, Spain \\ d Department of Forest Products Technology - Aalto University, Espoo, Finland \\ e Department of Forest Engineering of the State University of Mato Grosso do Sul, Brazil
}

\section{A R T I C L E I N F O}

\section{Article history:}

Received 18 June 2014

Received in revised form 17 October 2014

Accepted 21 October 2014

Available online 25 November 2014

\section{Keywords:}

Eucalypt

Pulping technology

Pulp

Wood chemistry

\begin{abstract}
A B S T R A C T
Wood utilization for pulp and paper and biorefinery applications requires some kind of mechanical and/or physical-chemical pretreatment. Among the chemical treatments the alkaline ones are the most used worldwide, although acid and solvent treatments have also being used. This paper deals with eucalypt wood deconstruction with alkaline processes including soda- $\mathrm{AQ}$ soda- $\mathrm{AQ}-\mathrm{O}_{2}$, soda- $\mathrm{O}_{2}$, and kraft. The kraft process is largely used by the pulp industry and is evaluated here only to serve as a reference. The behavior of the four eucalypt clones selected in chapter 2 were investigated when submitted to the aforementioned processes regarding their screened yield, chemical demands and pulp quality at different kappa number levels $(15,35,50$, and 70$)$. The two most promising processes (kraft and soda-AQ) were chosen for producing pulps (kappa 15 and 20) which were studied in depth (content of carbohydrates, uronic acid, hexenuronic acid, polysaccharide molecular weight, residual lignin structure, etc.), as well as their respective black liquors (heating value, solid content, elemental analysis, and lignin structure). The main findings of this work were: (1) the wood of the four different hybrid eucalypt clones behave similarly in the various alkaline deconstruction treatments; (2) the soda-AQ and Kraft were considered the most suitable processes for producing pulp on the basis of yield, chemical demands and pulp fiber integrity; (3) the soda-AQ process can potentially replace the kraft for a high degree of wood delignification (kappa number 15 ); (4) the alkaline processes using oxygen (soda- $\mathrm{AQ}-\mathrm{O}_{2}$ and soda- $\mathrm{O}_{2}$ ) are more suitable for wood deconstruction aimed at biofuels; and (5) the soda-AQ process resulted black liquor of more suitable burning characteristics than the kraft.
\end{abstract}

(c) 2014 Elsevier B.V. All rights reserved.

\section{Introduction}

The most common processes for pulping are the alkaline ones, with especial emphasis to the kraft process, which uses sodium hydroxide and sodium sulphide as main reagents. When targeting a new pulp industry working as a biorefinery, some processes changes such as sulphur free technologies shall be considered, since compounds containing this element are responsible for decreasing the black liquor heating value (Cardoso et al., 2009). Moreover,

\footnotetext{
* Corresponding author. Tel.: +55 3138992084.

E-mail addresses: fernando.gomes@ufv.br, fjbgomes@yahoo.com.br (F.J.B. Gomes).
}

sulphur is known to poison many catalytic reactions and would be negative to any high value application of the lignin extracted from black liquor (Vishtal and Kraslawski, 2011). Furthermore, sulfur free processes are interesting for decreasing environmental pressures, since the elimination of sulfur from the processes avoid TRS emissions that are typical of the kraft process (Alisson, 1983; Francis et al., 2008).

The soda based processes are interesting because they are compatible with the existing kraft pulping technology. The interest in sulfur-free pulping has centered on soda-anthraquinone (AQ) process, since AQ accelerates delignification and produces pulps with strength properties which approach that of kraft pulps (Francis et al., 2008; Gomide and Oliveira, 1980; Silva Júnior et al., 1996). Sulfur free pulping technologies such as 
Table 1

Codification of the eucalypt clones species.

\begin{tabular}{ll}
\hline Sample Code & Eucalypt clones species \\
\hline U1xU2 & E. urophylla $($ Flores IP $) \times$ E. urophylla $($ Timor $)$ \\
G1xUGL & E. grandis $($ Coffs Harbour $) \times[$ E. urophylla $(R) \times$ E. globulus $(R)]$ \\
DGxU2 & {$[$ E. dunnii $(R) \times$ E. grandis $(R)] \times$ E. urophylla $($ Timor $)$} \\
IP & E. urophylla $(I P) \times$ E. grandis $(I P)$ commercial clone \\
\hline
\end{tabular}

soda-anthraquinone-oxygen (soda-AQ- $\mathrm{O}_{2}$ ) and soda-oxygen ( oda- $\mathrm{O}_{2}$ ) have not been largely studied for eucalyptus wood (Khristova et al., 2006a,b; Francis et al., 2008).

This paper deals with eucalypt wood deconstruction with alkaline process including soda- $\mathrm{AQ}$, soda- $\mathrm{AQ}-\mathrm{O}_{2}$, soda- $\mathrm{O}_{2}$, and kraft aiming pulp production. The kraft process is largely used by the pulp industry and is evaluated here only to serve as a reference.

\section{Material and methods}

For this study, 4 eucalypt wood clone samples in commercial harvesting age were investigated, provided by GENOLYTPUS project, located in Minas Gerais State-Brazil. The complete list of samples used in this study is presented in Table 1.

Five representative trees of the population with average diameter at breast height and height were selected. They were harvested and from each tree it was extracted five $1 \mathrm{~m}$-long bolts at 0,25 , 50,75 , and $100 \%$ of the tree heights. The samples were evaluated for their moisture content at the moment of harvesting according to Tappi T264 cm-97 standard procedure. The eucalypt clone samples were chipped in a laboratory chipper, a Chogokukikai model, equipped with 3 knives and 2 screens (40 and $13 \mathrm{~mm}$ ); in the sequence, they were well mixed $\left(260 \mathrm{~m}^{3}\right.$ rotary mixer) and screened according to Scan-CN 40:94 procedure. The chips retained in the $3 \mathrm{~mm}$ and $7 \mathrm{~mm}$ screens were collected and mixed again, air dried to about $15 \%$ moisture and stored in large plastic bags.

\subsection{Methods}

Sampling for physical, chemical and morphological analyses was done by using the so-called quartering technique, which is trivial for those skilled in the art. Chips were used to measure chip bulk and basic density according to Scan-CN 49:92 and Scan-CM 46:92 standard procedures, respectively.

\subsubsection{Biomass productivity}

Biomass productivity was calculated by using the medium annual increase (MAI) and basic density, by the following equation:

Biomass productivity (ton/ha/yr)

$$
=\operatorname{MAI}\left(\mathrm{m}^{3} / \mathrm{ha} / \mathrm{yr}\right) \times \text { basic density }\left(\text { ton } / \mathrm{m}^{3}\right) \text {. }
$$

\subsubsection{Sample preparation for morphological analysis}

About 200 grams of each eucalypt clone sample were sliced into toothpick type material and macerated by using nitro-acetic acid solution in order to prepare individual fibers for morphological analyses. To make the maceration, a solution of five parts of acetic acid and one part of nitric acid were mixed, added to the biomass material until they were completely immersed and let stand for $6 \mathrm{~h}$ at $100^{\circ} \mathrm{C}$ under a hood. The reaction was stopped by washing the material, which was dispersed in distilled water. Following, the material was gently mixed in a magnetic stirrer (slowly and steadily) for $60 \mathrm{~min}$ so that all the fiber bundles were separated. Morphological characterization of fibers, vessels and fines was carried out on a pulp suspension passing through a specific cell illuminated by a laser beam and connected to a high-resolution camera (CCD). This analysis allowed reliable statistical measurement of thousands of fiber, vessels and fines to determine the main morphological and dimensional characteristics of the pulp components.

\subsubsection{Sample preparation for chemical analysis}

For the chemical analyses, about $1 \mathrm{~kg}$ of each eucalypt clone were sampled and ground in a Wiley type mill to produce sawdust of variable size. This sawdust was screened according to Tappi Standard T257-cm85. The sawdust that passed the 40 mesh screen and was retained in the 60 mesh screen was selected for the chemical analyses. The sawdust was air dried and conditioned in a temperature and humidity controlled room $\left(23 \pm 1^{\circ} \mathrm{C}, 50 \pm 2 \% \mathrm{RH}\right)$ until an equilibrium moisture was achieved $(\approx 10 \%)$. This sawdust (raw sawdust) was used for the chemical analyses. The analyses of ash, silica, chloride, iron, copper, manganese, potassium, calcium and magnesium were carried out directly on the raw sawdust, according to the Standard Methods for the Examination of Water and Wastewater (2000), except for chloride, which was determined according to Tappi T256 cm-97 standard procedure. The biomass extractive contents in acetone, ethanol/toluene (1:2) and ethanol/toluene $(1: 2) \rightarrow$ ethanol $\rightarrow$ hot water solvent series were also determined in the raw sawdust by using the Tappi T280 pm-99, T204 cm-97 and Tappi T264 cm-97 standard procedures, respectively. In order to determine biomass main cell wall components, a $200 \mathrm{~g}$ sample of extractives freed was prepared by using Tappi T264 cm-97 standard procedure. This extracted sample (extractive free sawdust) was conditioned in a temperature and humidity controlled room $\left(23 \pm 1{ }^{\circ} \mathrm{C}, 50 \pm 2 \% \mathrm{RH}\right)$ until an equilibrium moisture was achieved ( $\sim 10 \%)$. The contents of uronic acids, acetyl groups and sugars (glucans, mannans, galactans, xylans and arabinans) in the extractive free biomass were determined according to Scott (1979), Solar et al. (1987) and Wallis et al. (1996). The acid insoluble lignin, acid soluble lignin and lignin syringyl/guaiacyl $(\mathrm{S} / \mathrm{G})$ ratio were determined according to Tappi T222 om-97 standard procedure, Goldschmid (1971) and Lin and Dence (1992), respectively.

\subsubsection{Pulping: processes and conditions}

Four deconstruction processes were used to convert the eucalypt clones into pulps, namely: Soda-AQ, soda- $\mathrm{AQ}-\mathrm{O}_{2}$, soda- $\mathrm{O}_{2}$, and kraft. For analyzing the deconstruction processes five levels of kappa numbers were investigated: $15,20,35,50$ and 70 . The cooking trials of the eucalypt clones were done in an M\&K digester with 2 individual reactors of 10 liters each, equipped with a forced liquor circulation system and electrically heated with temperature and pressure control. The digester was coupled to a cooling system (Coil System with residual liquor, involved with water at room temperature), to ensure the cooling of the liquor after the cooking simulation. With the exception of the alkaline charge, the other deconstruction conditions were kept constant as shown in Table 2. Eight cooking experiments were performed for each sample and process, using different active alkali charge to establish the delignification curves.

Fiber individualization was achieved in a "hydrapulper" (15 liters capacity), followed by fine screening (Voith laboratory cleaner) equipped with perforated plates with $0.2 \mathrm{~mm}$ openings. The material retained on the sieve (rejects) was dried and weighed. The clean pulp was dewatered in centrifuge to a consistency of about $30 \%$, weighed and stored in polyethylene bags for further analysis. With the known weights of the sieved and retained materials, the reject content and the screened yield were determined. Pulp viscosity and brightness were measured in the screened material. 
Table 2

Conditions for pulping processes.

\begin{tabular}{|c|c|c|c|c|}
\hline Parameter & Soda-AQ process & Soda-AQ-O ${ }_{2}$ process & Soda- $\mathrm{O}_{2}$ process & Kraft process \\
\hline Chips (kg o.d.) & 1 & 1 & 1 & 1 \\
\hline Active alkali as $\mathrm{NaOH}$ (\% on o.d. chips) ${ }^{\mathrm{a}}$ & Variable & Variable & Variable & Variable \\
\hline Sulfidity as $\mathrm{NaOH}$ (\% on o.d. chips) & - & - & - & 26 \\
\hline Anthraquinone charge (\% on o.d. chips) & 0.05 & 0.05 & - & - \\
\hline Oxygen charge (\% on wood chips) & - & 6 & 6 & - \\
\hline Liquor to chips ratio $(\mathrm{L} / \mathrm{kg})$ & $4 / 1$ & $4 / 1$ & $4 / 1$ & $4 / 1$ \\
\hline Maximum temperature $\left({ }^{\circ} \mathrm{C}\right)$ & 170 & 170 & 170 & 170 \\
\hline Time to maximum temperature (min.) & 90 & 90 & 90 & 90 \\
\hline Time at maximum temperature (min.) & 50 & 50 & 50 & 50 \\
\hline
\end{tabular}

a The active alkali charge was investigated in various levels in order to reach kappa numbers 15, 20, 35, 50 and 70.

b In the Soda- $\mathrm{AQ}-\mathrm{O}_{2}$ and Soda- $\mathrm{O}_{2}$ processes, the oxygen dosage ( $6 \%$ on chip o.d. weight) was split into three parts and applied after 50 min, 70 min and 110 min reaction time from the beginning of cooking, thereby ensuring that the pressure limit $\left(20 \mathrm{kgf} / \mathrm{cm}^{2}\right)$ of the digester was not exceeded.

\subsection{Detailed pulp and black liquor characterization}

Detailed pulp and black liquor characterization were carried out only for the soda-AQ and kraft cooks terminated at kappa 15 and 20. These kappa numbers were chosen since they are most common values used by the eucalypt pulp industry worldwide. The pulps were evaluated regarding their carbohydrate molecular weight distribution, carbohydrate content, uronic acid, and hexenuronic acid content. For the determination of the molecular weight distribution Gel Permeation Chromatography (GPC) was used, in which the pulps were activated with dimethylacetamide before the GPC analysis through solvent exchange. The activated pulp samples were dissolved in DMAC/LiCl $9.0 \%(\mathrm{w} / \mathrm{v})$ at $80^{\circ} \mathrm{C}$ for $2 \mathrm{~h}$. Then, the solution was centrifuged at $4000 \mathrm{rev} / \mathrm{min}$ to remove undissolved components; thereafter the supernatant solution was analyzed. The calibration of the GPC columns was made with Pullulan reference materials (Agilent) in the range $0.18-778 \mathrm{kDa}$. The Data analysis was performed with LC Solution GPC software. The GPC analysis was performed on four serially connected columns PLgel Mixed A $300 \times 7.5 \mathrm{~mm}$ columns protected by a PLgel $20 \mathrm{~mm}$ pre-column (Polymer Laboratories Ltd, UK). The temperatures of the pre-column and columns, the injector, and the detector (RI) were kept constant at $80^{\circ} \mathrm{C}$. DMAC with $0.5 \%$ of $\mathrm{LiCl}(\mathrm{w} / \mathrm{v})$ was used as the eluent at a rate of $0.8 \mathrm{~mL} \mathrm{~min}^{-1}$, and the injection volume was $100 \mu \mathrm{L}$. The contents of uronic acids, acetyl groups, sugars (glucans and xylans), and hexenuronic acid were determined according to Scott (1979), Wallis et al. (1996), and Vuorinen et al. (1996).

The residual lignin isolated from soda-AQ and $\mathrm{k}$ raft pulps cooked to kappa number 15 and 20 of the clone G1xUGL (isolated from the pulps by acidolysis) as well as the lignin precipitated from their respective black liquors were analyzed by two-dimensional nuclear magnetic resonance (2D-NMR). The isolation of MWL and their structural characteristics were compared to those of the milled wood lignin (MWL) isolated from the initial raw material, a lignin preparation that is still considered to be the representative of the native lignin in the plant, despite its limitations (Guerra et al., 2006; Rencoret et al., 2009). The isolation of MWL from wood of the eucalypt clone G1xUGL was previously described by Prinsen et al. (2012). MWL was extracted from finely ball-milled $(15 \mathrm{~h})$ wood, free of extractives and hot water-soluble material, using dioxane-water $(9: 1, v / v)$, followed by evaporation of the solvent, and purified as described by Björkman (1956). The final yield ranged from $15 \%$ to $20 \%$ of the original Klason lignin content. For the isolation of residual lignin, first, all pulp samples were air-dried at $37-40^{\circ} \mathrm{C}$. Extractives were eliminated by Soxhlet extraction for $9 \mathrm{~h}$ with acetone and subsequent extraction with water at $100^{\circ} \mathrm{C}$ (three steps). Then, $15 \mathrm{~g}$ of dry pulp was subjected to acidolysis, according to the method previously described by Evtuguin et al. (2001), using a two-step extraction with $0.1 \mathrm{M} \mathrm{HCl}$ in a 1,4-dioxane:water mixture $(82: 18 \mathrm{v} / \mathrm{v})$ under an inert (argon) atmosphere at $88-92^{\circ} \mathrm{C}$. The solid:liquid ratio for the first and second extraction step was, respectively, 13.3 and $10.0 \mathrm{~mL}$ per gram of dry pulp. After the extractions, the pulp was washed with the same 1,4-dioxane:water mixture, but without $\mathrm{HCl}$. In order to avoid high acid concentration, the washing liquor was added equally to both extracts, which were evaporated separately under reduced pressure until a volume reduction of $\sim 70 \%$ was obtained. Both concentrated extracts were added together in $1.5 \mathrm{~L}$ of cold distilled water under strong stirring. The lignin was precipitated overnight at $4{ }^{\circ} \mathrm{C}$ and then centrifuged (25 min, $9000 \mathrm{rpm}, 4^{\circ} \mathrm{C}$ ). A washing step with cold distilled water was included, and after recovery ( $30 \mathrm{~min}, 9000 \mathrm{rpm}, 4^{\circ} \mathrm{C}$ ) the samples were freeze dried. The extraction yields of the residual lignins ranged from $60 \%$ to $82 \%$, based on the theoretical lignin content of pulp (\% lignin $=0.15 \times$ kappa number), except for the residual lignins from the pulps with kappa 15 , which were in the range of 26-30\%. The residual lignins were submitted to Soxhlet extraction with n-pentane during $8 \mathrm{~h}$. After drying with nitrogen, the residual lignin was ready for analysis. The lignins from the collected black liquors were precipitated at $\mathrm{pH} 4.0$ and the obtained slurries were air-dried at $40^{\circ} \mathrm{C}$. The homogenized samples were stored in a desiccator until stable humidity was attained. All analytical techniques $\left({ }^{1} \mathrm{H}-{ }^{13} \mathrm{C} 2 \mathrm{D}-\mathrm{NMR}\right.$, and $\left.{ }^{31} \mathrm{P} \mathrm{NMR}\right)$ were performed on these samples according previously methodologie which was described by Prinsen et al. (2012).

The two-dimensional nuclear magnetic resonance (2D-NMR) spectra were recorded at $25^{\circ} \mathrm{C}$ in a Bruker AVANCE $600 \mathrm{MHz}$ spectrometer, equipped with a cryogenically cooled z-gradient triple resonance probe. Forty milligrams ( $40 \mathrm{mg}$ ) of lignin sample were dissolved in $0.75 \mathrm{~mL}$ of dimethylsulfoxide (DMSO)-d6, and ${ }^{1} \mathrm{H}-{ }^{13} \mathrm{C}$ HSQC (heteronuclear single quantum correlation) spectra were recorded. The spectral widths were 5000 and $13,200 \mathrm{~Hz}$ for the ${ }^{1} \mathrm{H}$ and ${ }^{13} \mathrm{C}$ dimensions, respectively. The number of collected complex points was 2048 for the ${ }^{1} \mathrm{H}$ dimension, with a recycle delay of $1 \mathrm{~s}$. The number of transients was 64 , and 256 time increments were recorded in the ${ }^{13} \mathrm{C}$ dimension. The ${ }^{1} J_{\mathrm{CH}}$ constant was set to $140 \mathrm{~Hz}$. The J-coupling evolution delay was set to $3.2 \mathrm{~ms}$. Squared cosine-bell apodization function was applied in both dimensions. Prior to Fourier transformation, the data matrices were zero-filled up to 1024 points in the ${ }^{13} \mathrm{C}$ dimension. The central solvent peak was used as an internal reference ( $\delta \mathrm{C} 39.5 \mathrm{ppm} ; \delta H 2.49 \mathrm{ppm}$ ). HSQC cross-signals were assigned by comparing with the literature (Capanema et al., 2004; Ibarra et al., 2007; Rencoret et al., 2009, 2011). In the aromatic region, $\mathrm{C} 2,6-\mathrm{H} 2,6$ correlations from $\mathrm{S}$ units and $\mathrm{C} 2-\mathrm{H} 2$ correlations from $\mathrm{G}$ units were used to estimate the $\mathrm{S} / \mathrm{G}$ lignin ratios. The abundances of the different inter unit linkages were referred to the number of aromatic units (per 100 aromatic units), to obtain a comparative estimation of their removal during pulping.

Concerning the black liquor heating value, solids, sodium, silicate, and chloride were determined according to Tappi T684 om-11, CPPA H1, Tappi T25 cm-85, Tappi T244, and Tappi T699 om-87. The elemental analysis (including $\mathrm{C}, \mathrm{H}, \mathrm{N}, \mathrm{S}$, and $\mathrm{O}$ ), and potassium were 
Table 3

Wood productivity and physical characteristics of the eucalypt clones evaluated.

\begin{tabular}{|c|c|c|c|c|c|}
\hline Sample code & Moisture (\%) & $\begin{array}{l}\text { Average annual } \\
\text { increment }\left(\mathrm{m}^{3} / \mathrm{ha} / \mathrm{yr}\right)^{*}\end{array}$ & $\begin{array}{l}\text { Wood basic density } \\
\left(\mathrm{kg} / \mathrm{m}^{3}\right)\end{array}$ & $\begin{array}{l}\text { Wood productivity } \\
\text { (bone dry ton/ha/yr) }\end{array}$ & $\begin{array}{l}\text { Chip bulk density } \\
\left(\mathrm{kg} / \mathrm{m}^{3}\right)\end{array}$ \\
\hline U1xU2 & 54 & 86.0 & 504 & 43.3 & 209 \\
\hline G1xUGL & 53 & 46.2 & 500 & 23.1 & 202 \\
\hline DGxU2 & 56 & 101.6 & 496 & 50.4 & 203 \\
\hline IP & 55 & 80.9 & 480 & 38.8 & 183 \\
\hline
\end{tabular}

determined by using elemental analyzer equipment and atomic absorption spectrometer, respectively.

\section{Results and discussion}

\subsection{Wood productivity, morphology and physical-chemical characteristics}

\subsubsection{Wood productivity and physical properties}

The average annual increment (AAI) varied in the range of 46.2-101.6 $\mathrm{m}^{3} / \mathrm{ha} / \mathrm{yr}$ (Table 3). The lowest AAI occurred for the G1xUGL clone and the highest for the DGxU2 clone. However, even the one with lowest AAI may be considered satisfactory given that the average for Brazilian commercial plantations is $40-60 \mathrm{~m}^{3} / \mathrm{ha} / \mathrm{yr}$ (Bracelpa, 2013).

Two very important factors regarding biomass use in industrial processes are moisture content and density, since they affect harvesting, transportation and utilization costs. The eucalypt clones analyzed in this study showed similar values of moisture (minimum 53\% and maximum 56\%) and density varying from 480 to $504 \mathrm{~kg} / \mathrm{m}^{3}$. These values are considered satisfactory for pulp production (Dias and Cláudio-Da-Silva, 1991; Wehr and Barrichello, 1993; Silva JR. et al., 1996, Gomide et al., 2005).

\subsubsection{Wood morphological characteristics}

The strength and morphology of fibers have a strong influence on the physical properties of paper (Seth and Page, 1988; Foelkel, 2007; Mokfienski et al., 2008). In Table 4, the morphological characterizations of the eucalypt clones are presented. The values of width, length, coarseness, macro fibrillation index were somewhat similar for the four eucalypt samples. Concerning fine contents, the values were also similar among the samples, except for the IP clone, which presented a highest fine content. Due to a high surface area, and high swelling, fines affect paper sheet structure and properties in several ways, including increased sheet wetness for given dewatering conditions and increased fiber interaction by increasing the fiber water-air interfaces where the surface tension forces act during sheet drying (Seth, 2003).
The vessel contents were different among the eucalypt clones, the low value was observed for the DGxU2 clone, and the high value was observed to G1xUGL one. For the pulping process, the vessel elements are desirable, since they facilitate penetration of cooking liquors. However, for the production of special kinds of paper, such as the printing papers, they are considered undesirable, because the vessel on the surface of the paper sheet tend to be pulled, thereby causing printing failures known as "vessels picking" (Lindströn and Fardim, 2012).

\subsubsection{Wood chemical properties}

Table 5 shows the extractive quantity of the eucalypt clones samples extracted with the ethanol/toluene $\rightarrow$ ethanol $\rightarrow$ hot water solvent series, with ethanol/toluene 1:2 only and with acetone. In order to measure the biomass cell wall components, it is relevant to remove all extractives present in the material. The Tappi T204 CM 97 standard procedure (ethanol/toluene 1:2 $\rightarrow$ ethanol $\rightarrow$ hot water) was efficient for removing all polar and apolar extractive fractions. Although this procedure is intended to free the wood from extractives, it serves also to quantify the total amount of extractives present in the biomass, since the main cell wall components (cellulose, hemicelluloses and lignins) are not soluble in none of the solvents comprising the series. Extraction with ethanol/toluene only extracts substances as waxes, fats, resins, phytosterols and non-volatile hydrocarbons. Extraction in acetone (Tappi 280 PM99) serves to quantify those extractives that are more relevant to the pulping operation and pitch formation in the pulp. The acetone extractable content of wood is a measure of such substances as fatty acids, resin acids, sterols, waxes and non-volatile hydrocarbons. Because acetone is both more polar and water-miscible than dichloromethane or benzene-ethanol, the quantity of acetone extractable material, especially in wood, may be higher than that found with the other solvents. This procedure will not give the same results as ethanol-toluene or dichloromethane extractions. In his work, Barbosa et al. (2005) showed that acetone is the best solvent for the evaluation of the wood lipophilic extract content.

Biomass extractives are quite troublesome since they cause many difficulties in operating the industrial facilities, causing

Table 4

Fiber and vessels characterization of the eucalypt clones evaluated.

\begin{tabular}{|c|c|c|c|c|}
\hline \multirow[t]{2}{*}{ Sample code } & \multicolumn{4}{|c|}{ Eucalypt clones } \\
\hline & $\mathrm{U} 1 \mathrm{xU} 2$ & G1xUGL & DGxU2 & IP \\
\hline Fiber content (millions/g of pulp) & 29.8 & 27.9 & 31.6 & 28.1 \\
\hline Mean fiber arithmetic length $(\mu \mathrm{m})$ & 617.5 & 635.0 & 622.5 & 562.0 \\
\hline Mean length-weighted fiber length $(\mu \mathrm{m})$ & 746.5 & 779.5 & 763.0 & 733.0 \\
\hline Mean area-weighted length $(\mu \mathrm{m})$ & 742.5 & 775.0 & 768.0 & 733.5 \\
\hline Mean fiber width $(\mu \mathrm{m})$ & 16.0 & 16.5 & 17.6 & 16.4 \\
\hline Mean fiber coarseness $(\mathrm{mg} / \mathrm{m})$ & 0.05 & 0.05 & 0.05 & 0.06 \\
\hline Mean fiber curl index (\%) & 4.5 & 5.0 & 4.2 & 4.5 \\
\hline Macro-Fibrillation index (\%) & 0.48 & 0.45 & 0.49 & 0.54 \\
\hline Broken fiber content (\%) & 14.6 & 15.0 & 16.4 & 17.7 \\
\hline Fine content (\% in area) & 7.8 & 8.0 & 8.0 & 12.4 \\
\hline Mean fine area $\left(\mu \mathrm{m}^{2}\right)$ & 1707 & 1661 & 1574 & 1647 \\
\hline Mean fine length ( $\mu \mathrm{m})$ & 65.5 & 66.0 & 61.5 & 64.5 \\
\hline Vessel content (nb/g of pulp) & 8132 & 10795 & 1774 & 6771 \\
\hline Mean area-weighted length (mm) & 0.41 & 0.44 & 0.32 & 0.43 \\
\hline Mean vessel width $(\mu \mathrm{m})$ & 186.5 & 185.0 & 182.8 & 194.3 \\
\hline
\end{tabular}


Table 5

Extractive content of the eucalypt clones evaluated.

\begin{tabular}{|c|c|c|c|}
\hline Sample code & Acetone extractives (\%) & Ethanol/toluene (1:2) extractives (\%) & Total extractives (\%) \\
\hline $\mathrm{U} 1 \mathrm{xU} 2$ & 1.7 & 1.9 & 3.6 \\
\hline G1xUGL & 2.5 & 2.5 & 4.9 \\
\hline DGxU2 & 1.2 & 2.2 & 2.7 \\
\hline IP & 0.8 & 1.5 & 2.3 \\
\hline
\end{tabular}

Table 6

Ash and metal content of the eucalypt clones evaluated.

\begin{tabular}{|c|c|c|c|c|c|c|c|c|}
\hline \multirow[t]{2}{*}{ Sample code } & \multicolumn{8}{|c|}{ Inorganics (mg/kg wood) } \\
\hline & Ash & $\mathrm{Cu}$ & $\mathrm{Fe}$ & $\mathrm{Ca}$ & $\mathrm{Mn}$ & $\mathrm{Mg}$ & K & $\mathrm{Cl}^{-}$ \\
\hline U1xU2 & 950.0 & 0.8 & 15.5 & 307.0 & 9.5 & 81.0 & 194.0 & 260.0 \\
\hline G1xUGL & 1950.0 & 0.5 & 13.1 & 452.0 & 14.0 & 112.0 & 188.0 & 629.0 \\
\hline DGxU2 & 2280.0 & 1.2 & 13.5 & 531.0 & 13.2 & 123.0 & 218.0 & 427.0 \\
\hline IP & 1550.0 & 1.1 & 9.3 & 378.0 & 18.2 & 104.0 & 369.0 & 434.0 \\
\hline
\end{tabular}

unexpected lost time in the operation for cleaning of equipment and instruments due to their stickiness and tackiness. In addition may occur the deposition of these substances in the pulp, which are called pitch (Barbosa et al., 2005), decreasing the pulp value or even its rejection by market. In her study Cruz et al. (2006) showed that in pitch composition are present waxes, fats, long chain alcohols, being these main compounds associated with pitch formation (Karlsson et al., 2001).

The evaluated eucalypt clones showed acceptable acetone extractives, Ethanol/Toluene (1:2) extractives and total extractive contents for the pulp mills (Gomide et al., 2010). The highest value was observed to G1xUGL clone. In addition, pitch formation and pulp dirtiness are much more likely on raw materials containing high content of these extractives (Barbosa et al., 2005), another negative aspect of materials with high extractive content is that they are likely to result low yield during cooking process.

Wood minerals are detrimental for industrial utilization, since they cause corrosion and deposits on equipment, reduce biomass heating value and decrease mill throughput. The results of wood mineral content presented in Table 6 show generally low amounts of inorganics in the eucalypt woods (Moreira, 2006; Foelkel, 1997). For the eucalypt clones, the total inorganics measured by complete biomass combustion (ash content) varied in the range of $950-1550 \mathrm{mg} / \mathrm{kg}$ wood.

In Table 7 , the results of the analysis of content of sugar, acetyl group, uronic acids, lignin and syringyl/guaiacyl ratio from ligninare presented. Among the woody biomass, there were significant variations among the total lignin contents, in the range of 27.2-30.3\%; the maximum value was obtained for the U1xC2 hybrid and the minimum for the G1xGL2 one. However, these values are considered acceptable for eucalypt clones, but for pulp production a lower lignin content and high $S / G$ ratio are desired due to the increase of the pulpability of the wood (Gomes et al., 2008; Gomide et al., 2005). About the carbohydrate content, the eucalypt clones presented values considered satisfactory for eucalypts for pulp production (Gomide et al., 2005).

\subsection{Wood pulpability}

The chemistry and efficiency of alkaline pulping technologies are influenced by several process parameters, alkali charge and the possible addition of tother cooking chemicals, e.g. sulphide or anthraquinone (Lehto and Alén, 2013). Currently, Kraft pulping is the dominant process for the delignification of wood into pulp. The key to the kraft process is the kraft recovery cycle that is quite efficient at recovering the pulping chemicals, $\mathrm{NaOH}$ and $\mathrm{Na}_{2} \mathrm{~S}$ (Vakilainen, 2000). However, energy efficiency is becoming more important each passing year and there is a sense of inevitability that gasification of the pulping effluent or black liquor will replace the kraft recovery cycle for chemical and energy recovery (Bose et al., 2009). The technical feasibility of black liquor gasification would improve significantly if a non-sulfur pulping process were used to replace kraft (Francis et al., 2008). In this context, soda pulping which is traditionally the most employed chemical pulping process for various different types of raw materials (Khristova et al., 2006a,b; Enayati et al., 2009) appears as an interesting alternative. However, the soda pulping produces a low yield and highly colored pulp, consuming a large amount of bleaching chemicals (Francis et al., 2006; Labid et al., 2008). Some these disadvantages of soda pulping could be overcome by the using of pulping additives. The addition of anthraquinone (AQ) to soda pulping liquor is known as an effective and simple approach that increases delignification selectivity, carbohydrate protection, and pulp yield (Hamzeh et al., 2009). A study conducted by Almeida and Gomide (2013)

Table 7

Chemical composition of the eucalypt clones evaluated.

\begin{tabular}{|c|c|c|c|c|c|}
\hline Sample code & & U1xU2 & G1xUGL & DGxU2 & IP \\
\hline Total Extractives (\%) & & 3.6 & 4.9 & 2.7 & 2.3 \\
\hline Total ash (\%) & & 0.1 & 0.2 & 0.23 & 0.16 \\
\hline \multirow[t]{5}{*}{ Sugar Composition (\%) } & Glucans & 46.1 & 43.9 & 45.3 & 49.4 \\
\hline & Xylans & 11.8 & 13.0 & 12.6 & 12.0 \\
\hline & Galactans & 0.8 & 0.8 & 0.9 & 1.2 \\
\hline & Mannans & 0.8 & 0.9 & 1 & 0.9 \\
\hline & Arabinans & 0.2 & 0.2 & 0.3 & 0.3 \\
\hline Acid Soluble Lignin (\%) & & 4.3 & 4.7 & 4.4 & 4.2 \\
\hline Total lignin (\%) & & 30.3 & 28.9 & 29.8 & 27.2 \\
\hline Lignin $S / G$ ratio & & 2.8 & 2.9 & 2.6 & 2.7 \\
\hline Acetyl Group (\%) & & 2.1 & 2.7 & 2.5 & 1.9 \\
\hline Uronic Acid Group (\%) & & 3.7 & 3.8 & 4.0 & 4.0 \\
\hline
\end{tabular}


shown that the anthraquinone addition increases the soda pulping screened yield level and, for some dosages, this yield turns out higher than the Kraft yield; indicating that this process seems to be the ideal for replacing the kraft. The cooking results for all materials and processes evaluated are presented in Table 8. Among the eucalypt clones, it was possible to observe slightly high and slightly low alkali demand for the materials U1xU2 and IP, respectively, when aiming to low kappa numbers, a result that can be traced to their high and low lignin contents, respectively. The other eucalypt clones showed similar chemical consumptions

Additionally, alternative processes can also be used when it is desired to obtain other products besides pulp, such as soda-AQ- $\mathrm{O}_{2}$ and soda- $\mathrm{O}_{2}$. The oxygen addition in the pulping processes greatly improves the delignification rate, which is very suitable for pulping processes (Rovio et al., 2011). On the other hand, the oxidative conditions affect the fiber ultrastructure in a deconstructive manner (Chang et al., 2001; Rovio et al., 2011). Since that these processes have a more drastic consequence for the mechanical fiber properties, they can be considered a promising alternative for replacing the kraft and soda-AQ as pretreatment for biorefinery processes. In contrast to paper grade pulps, when aiming some biorefinery applications such as bioethanol, the pulp strength is not important. In these cases, the deconstruction of the lignocellulosic matrix is aimed at the removal and/or modifications of the lignin in order to improve substrate digestibility (Chen et al., 2013).

A comparison of the different deconstruction methods indicate the soda- $A Q-O_{2}$ and soda- $\mathrm{O}_{2}$, as the most drastic since they presented high alkali demand to achieve a given degree of delignification (Table 8). As expected, the kraft process consumed the lowest amount of alkali to achieve the desired kappa number among all alkaline processes.

On the other hand, although all processes could be considered satisfactory regarding their viscosity values, soda-AQ and kraft presented the highest values for this parameter, indicating less carbohydrate degradation (Fig. 1). It can be explained due to selectivity effect of the AQ (Khristova et al., 2006a,b), and low alkaline charge applied in the kraft process. Concerning the pulp brightness, it was observed a similar behavior among the samples and deconstruction processes evaluated (Fig. 2).

Regarding the yield, soda- $\mathrm{O}_{2}$ showed the worst performance among the studied processes. The soda-AQ- $\mathrm{O}_{2}$ showed a slightly better yield performance than soda-AQ, in spite of the high alkali demand, but the pulp presented low viscosity. In general, the kraft process presented the best performance when all parameters are considered.

In this way, the two chosen processes were: soda-AQ and Kraft, and as previously described in the methodology pulps were produced by these processes at kappa number 15 and 20, using the established conditions curves obtained in the pulpability study; the results of these pulping processes are presented in Table 9.

\subsection{Pulp characterization}

The soda-AQ and kraft pulps of kappa number 15 and 20 were evaluated regarding their contents of carbohydrate, uronic acids and hexenuronic acids (Table 10). Regarding the carbohydrate content, the soda-AQ presented the highest glucans content, which can be explained due to $\mathrm{AQ}$ effect preserving these polymers against the peeling reactions during the pulping process (Khristova et al., 2006a,b). On the other hand, concerning the xylans content, the kraft pulps showed highest contents, which reflected on the highest uronic acid and hexenuronic acids contents in these pulps. In addition, more xylans were also found in the kappa $20 \mathrm{kraft}$ pulp in relation to the kappa 15 one. Concerning the pulp chemical composition among the eucalypts studied, considering each evaluated process, it was observed the same trend among them. In general, the

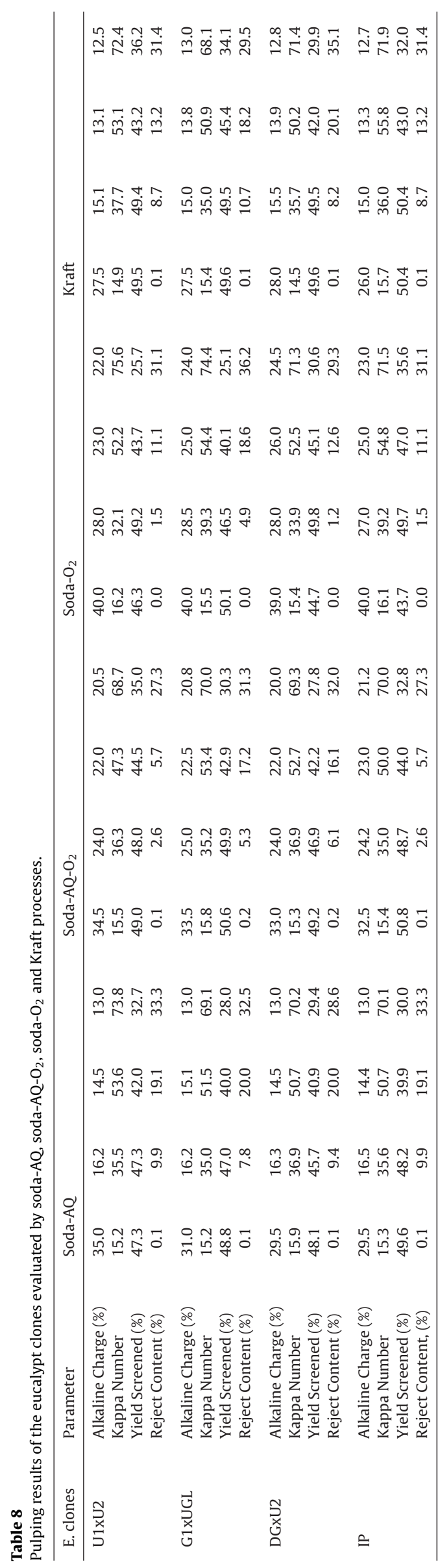



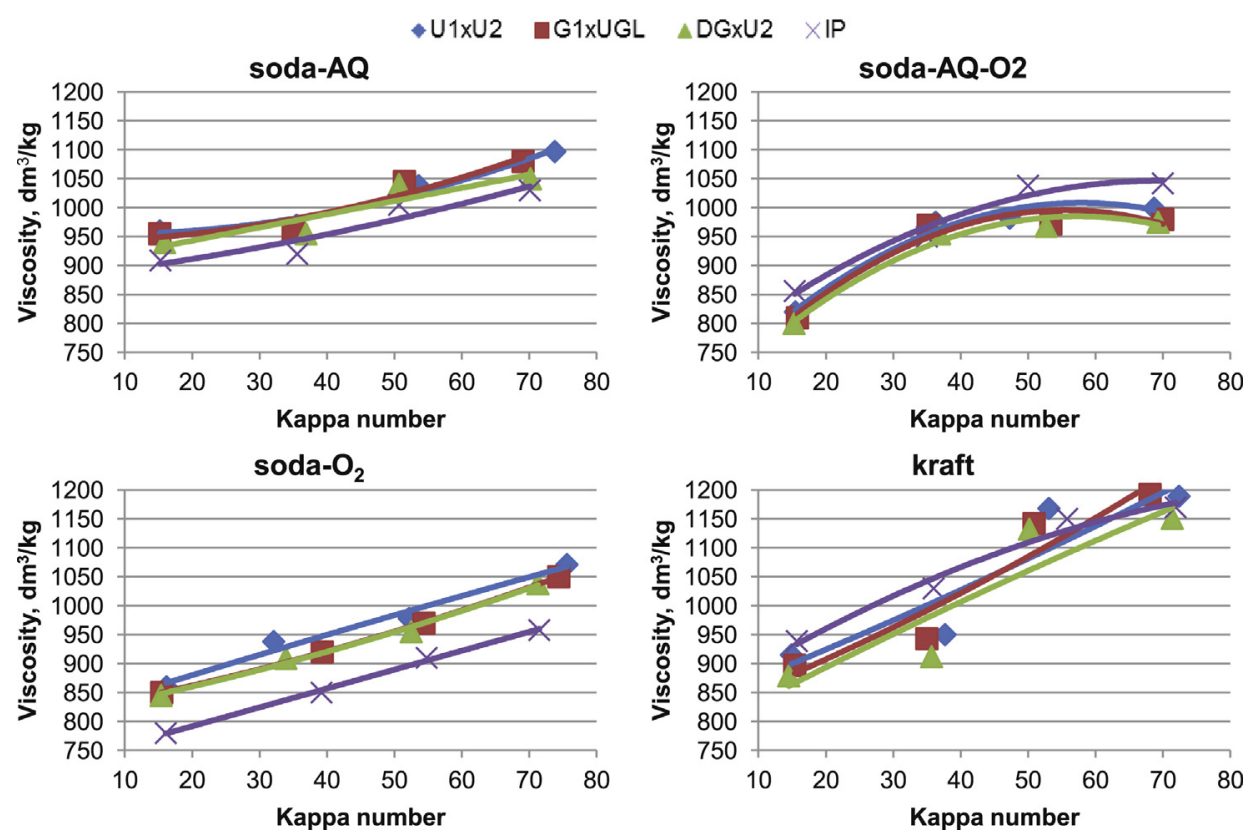

Fig. 1. Viscosity versus kappa number for the processes and raw materials evaluated.

pulps cooked at kappa 15 showed lower xylan contents than those cooked to kappa 20, indicating that these carbohydrates are penalized when the pulping process is conducted aiming lower kappa number.

Regarding the hexenuronic acid content, a positive point of the soda-AQ process is its low generation of this acid, e.g. a bleachability of theses pulps are positively impacted; it has been documented in the literature that pulps with lower hexenuronic acid content have a greater performance in the O-stage, since small amounts of hexenuronic acid are removed during oxygen delignification (Eiras, 2003). Another relevant point for bleaching processes which may be also attractive in soda-AQ pulps is that they present higher content of free phenolic hydroxyl groups
(Francis et al., 2005; Bose et al., 2009), which are the main sites for oxygen reactions (Colodette et al., 2007). It is known that in soda-AQ pulping, AQ oxidizes the reducing end groups of carbohydrates, thus stabilizing them towards peeling reactions in alkaline media. The reduced form, AQ, cleaves part of the $\beta$ aryl ether linkages in lignin. Thus, the molecular mass of the residual lignin is reduced and new phenolic hydroxyl groups are formed. Both effects render the lignin more soluble (Kleen et al., 2002). Since phenolic hydroxyl groups are essential to lignin dissolution in alkali, a higher content of this functional group in the residual lignin may be partly related to the residual lignin being more condensed. In his work, Zong Lai (1999) showed that the tendency of alkaline lignin condensation reactions would
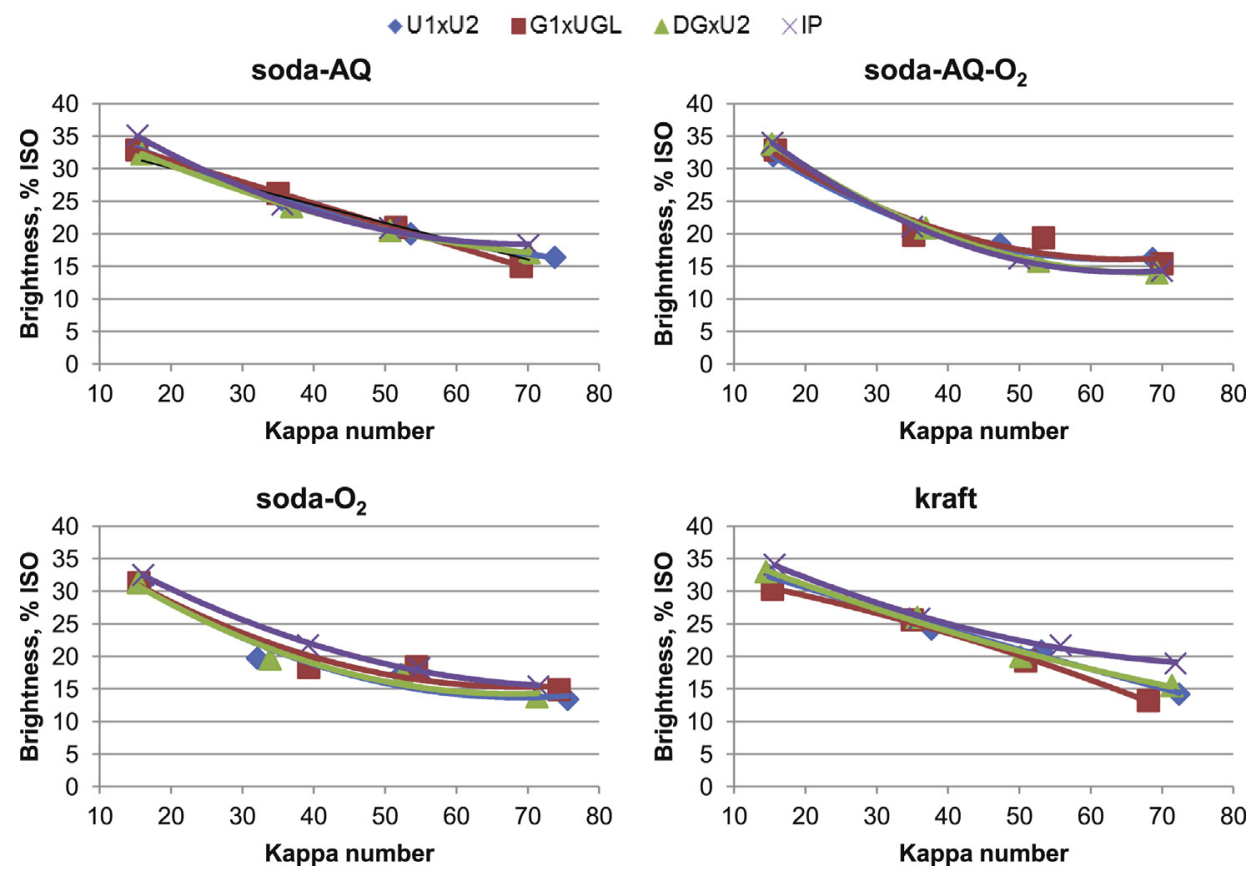

Fig. 2. Brightness versus kappa number for the processes and raw materials evaluated. 
Table 9

Pulping results for the soda-AQ and Kraft processes at kappa number 15 and 20.

\begin{tabular}{|c|c|c|c|c|c|}
\hline \multirow[t]{2}{*}{ Eucalypt clones } & \multirow[t]{2}{*}{ Parameter } & \multicolumn{2}{|l|}{ Soda-AQ } & \multicolumn{2}{|l|}{ Kraft } \\
\hline & & Kappa 15 & Kappa 20 & Kappa 15 & Kappa 20 \\
\hline \multirow{5}{*}{$\mathrm{U} 1 \mathrm{xU} 2$} & Alkali Charge (\% NaOH) & 35.0 & 24.0 & 27.5 & 22.0 \\
\hline & Screened yield (\%) & 47.3 & 50.0 & 49.5 & 51.2 \\
\hline & Reject Content (\%) & 0.1 & 1.1 & 0.1 & 0.3 \\
\hline & Viscosity $\left(\mathrm{dm}^{3} / \mathrm{kg}\right)$ & 875 & 919 & 1032 & 1073 \\
\hline & Brightness (\% ISO) & 33.3 & 30.8 & 33.5 & 31.9 \\
\hline \multirow[t]{5}{*}{ G1xUGL } & Alkali Charge (\% $\mathrm{NaOH})$ & 31.0 & 23.0 & 27.5 & 21.0 \\
\hline & Yield Screened (\%) & 47.0 & 51.0 & 49.6 & 50.4 \\
\hline & Reject Content (\%) & 0.1 & 0.2 & 0.1 & 0.5 \\
\hline & Viscosity $\left(\mathrm{dm}^{3} / \mathrm{kg}\right)$ & 748 & 917 & 1144 & 1193 \\
\hline & Brightness (\% ISO) & 34.0 & 32.1 & 32.3 & 30.6 \\
\hline \multirow[t]{5}{*}{ DGxU2 } & Alkali Charge (\%) & 29.5 & 22.0 & 28.0 & 22.0 \\
\hline & Screened yield (\%) & 48.1 & 51.1 & 49.6 & 52.0 \\
\hline & Reject Content (\%) & 0.1 & 0.4 & 0.1 & 0.4 \\
\hline & Viscosity $\left(\mathrm{dm}^{3} / \mathrm{kg}\right)$ & 951 & 1020 & 892 & 1054 \\
\hline & Brightness (\% ISO) & 34.0 & 30.8 & 34.3 & 31.8 \\
\hline \multirow[t]{5}{*}{ IP } & Alkali Charge (\%) & 29.5 & 22.0 & 26.0 & 20.0 \\
\hline & Yield Screened (\%) & 49.6 & 51.6 & 50.4 & 52.0 \\
\hline & Reject Content (\%) & 0.2 & 0.6 & 0.1 & 0.4 \\
\hline & Viscosity $\left(\mathrm{dm}^{3} / \mathrm{kg}\right)$ & 972 & 1028 & 939 & 1100 \\
\hline & Brightness (\% ISO) & 34.0 & 29.6 & 33.3 & 31.1 \\
\hline
\end{tabular}

Table 10

Results of glucan, xylans, uronic acid, and hexenuronic acid content of pulps obtained by the Soda-AQ and Kraft processes at kappa numbers 15 and 20.

\begin{tabular}{|c|c|c|c|c|c|c|c|c|c|}
\hline & & \multicolumn{4}{|l|}{ Kappa 15} & \multicolumn{4}{|l|}{ Kappa 20} \\
\hline & & Glucans (\%) & Xylans (\%) & Uronic Acids (\%) & $\operatorname{HexA}(\mathrm{mmol} / \mathrm{kg})$ & Glucans (\%) & Xylans (\%) & Uronic Acids (\%) & $\operatorname{HexA}(\mathrm{mmol} / \mathrm{kg})$ \\
\hline \multirow{4}{*}{ Soda-AQ } & U1xU2 & 88.1 & 8.5 & 0.2 & 15.8 & 84.9 & 11.3 & 0.5 & 40.3 \\
\hline & G1xUGL & 86.2 & 10.4 & 0.3 & 21.2 & 83.9 & 12.2 & 0.7 & 48.2 \\
\hline & DGxU2 & 88.0 & 8.8 & 0.3 & 15.9 & 84.2 & 11.8 & 0.6 & 43.4 \\
\hline & IP & 87.1 & 9.6 & 0.3 & 21.8 & 84.5 & 11.2 & 0.6 & 45.7 \\
\hline \multirow[t]{4}{*}{ Kraft } & $\mathrm{U} 1 \mathrm{xU} 2$ & 82.0 & 13.9 & 0.6 & 39.8 & 81.2 & 14.2 & 1.3 & 48.8 \\
\hline & G1xUGL & 81.6 & 15.4 & 0.7 & 41.8 & 80.8 & 15.8 & 1.2 & 48.6 \\
\hline & DGxU2 & 82.2 & 13.4 & 0.7 & 39.1 & 81.2 & 14.0 & 1.3 & 48.9 \\
\hline & IP & 81.9 & 14.0 & 0.6 & 39.5 & 80.6 & 14.9 & 1.3 & 46.4 \\
\hline
\end{tabular}

increase in the order of: high sulfidity $<$ kraft $<$ soda-AQ $<$ soda cooks.

The soda-AQ pulps at kappa number 20 presented satisfactory values to DP, which were similar to those found for kraft pulps at kappa number 15 (Table 11). Concerning the pulp viscosities, they presented an expected behavior, decreasing with the DP decrease. Another interesting finding is that in spite of low xylans content. The polydispersity of xylans is lower than that of glucans regardless of the pulp sample (Table 12). Among the eucalypts studied, the U1xU2 pulp presented the highest DP among all pulps.

Table 13 present results of 2D-NMR analysis of lignin isolated from kraft and soda-AQ pulps of kappa 15 and 20, derived from the G1xUGL eucalypt clone, which is a triple crossing hybrid of Eucalyptus grandis $\times$ (Eucalyptus urophylla $\times$ Eucalyptus globulus); it was selected due to its high xylan content and for possessing Eucalyptus globulus in its genotype, which is of interest for its high $\mathrm{S} / \mathrm{G}$ ratio, although it is quite challenging for its high content of extractives (4.9\%), being an interesting raw material for a detailed study. A quantification of the abundance of the main lignin interunit linkages present in the different residual lignin, as well as the abundance of the $G$ and $S$ lignin units was performed by integration of the volume contours of their cross-signals and was referred to as per 100 aromatic units (Table 13). The main linkages observed in the residual lignin from G1xUGL were $\beta-0-4^{\prime}$ aryl ether, $\beta-\beta^{\prime}$ resinol and $\beta-5^{\prime}$ phenylcoumaran structures, in both the soda-AQ and kraft pulps. No oxidized lignin moieties were observed by 2D-NMR in this residual lignin.
The distributions of the different inter-unit linkages in the pulp residual lignin is similar to that observed in the native lignin in wood, with a predominance of $\beta$-O-4 alkyl-aryl ether linkages, followed by lower amounts of resinols and phenylcoumaran, although with a drastic reduction in their content. This reduction in the content of linkages was more evident in the pulps with lower kappa number (kappa 15) than in pulps with higher kappa number (kappa 20) due to the more drastic pulping conditions at lower kappa numbers. Moreover, at similar kappa number, the content of $\beta-0-4^{\prime}$ aryl ether linkages in the residual lignin were lower for the soda-AQ process that for the kraft process, indicating a higher efficiency of the soda-AQ process for delignifying the G1xUGL eucalypt wood.

\subsection{Black liquor characterization}

The material dissolved in the black liquor consists mainly of lignin and degraded carbohydrates (hemicelluloses and cellulose), while the minor part are extractives, proteins and inorganic constituents (Cardoso et al., 2009). Table 14 presented the results of black liquor heating value, total solids, inorganic solids, and organic solids. Results of inorganic/organic mass demonstrate that the eucalypt clones as processed by soda-AQ and kraft processes possess an average of $46.5 \%(44.1-49.8 \%)$ inorganic and $53.2 \%$ (50.2-56.3\%) organic materials.

The soda-AQ process would be an excellent solution compared to kraft process, since the black liquor from this process presents a higher heating value than the kraft black liquor and it is a sulfur free process. The absence of sulfur compounds in the soda-AQ black 
Table 11

Degree of polymerization (DP) and intrinsic viscosity of eucalyptus kraft and soda-AQ pulps cooked to kappa 15 and 20.

\begin{tabular}{|c|c|c|c|c|c|c|c|}
\hline & & \multicolumn{3}{|l|}{ Kappa 15} & \multicolumn{3}{|l|}{ Kappa 20} \\
\hline & & Glucans DP & Xylans DP & $\begin{array}{l}\text { Pulp Visc., } \\
\mathrm{dm}^{3} / \mathrm{kg}\end{array}$ & Glucans DP & Xylans DP & Pulp Visc., $\mathrm{dm}^{3} / \mathrm{kg}$ \\
\hline \multirow[t]{4}{*}{ Soda-AQ } & U1xU2 & 4986 & 296 & 875 & 6416 & 313 & 919 \\
\hline & G1xUGL & 4745 & 266 & 748 & 6310 & 281 & 917 \\
\hline & DGxU2 & 4603 & 180 & 951 & 5951 & 256 & 1020 \\
\hline & IP & 5007 & 277 & 972 & 6218 & 297 & 1028 \\
\hline \multirow[t]{4}{*}{ Kraft } & U1xU2 & 6939 & 199 & 1032 & 7340 & 265 & 1073 \\
\hline & G1xUGL & 6030 & 233 & 1144 & 8114 & 244 & 1193 \\
\hline & DGxU2 & 5672 & 222 & 892 & 6965 & 269 & 1054 \\
\hline & IP & 5376 & 257 & 939 & 6935 & 254 & 1100 \\
\hline
\end{tabular}

Table 12

Polydispersity of eucalyptus kraft and soda-AQ pulps cooked to kappa number 15 and 20.

\begin{tabular}{|c|c|c|c|c|c|}
\hline & & \multicolumn{2}{|l|}{ Карра 15} & \multicolumn{2}{|l|}{ Kappa 20} \\
\hline & & Glucans DP & Xylans DP & Glucans DP & Xylans DP \\
\hline \multirow[t]{4}{*}{ Soda-AQ } & U1xU2 & 2.46 & 1.14 & 2.04 & 1.17 \\
\hline & G1xUGL & 2.29 & 1.12 & 2.09 & 1.29 \\
\hline & DGxU2 & 2.79 & 1.61 & 2.31 & 1.50 \\
\hline & IP & 2.33 & 1.17 & 2.19 & 1.26 \\
\hline \multirow[t]{4}{*}{ Kraft } & $\mathrm{U} 1 \mathrm{xU} 2$ & 1.91 & 1.71 & 2.26 & 1.35 \\
\hline & G1xUGL & 2.42 & 1.52 & 2.37 & 1.37 \\
\hline & DGxU2 & 2.19 & 1.65 & 2.21 & 1.33 \\
\hline & IP & 2.31 & 1.37 & 2.14 & 1.29 \\
\hline
\end{tabular}

Table 13

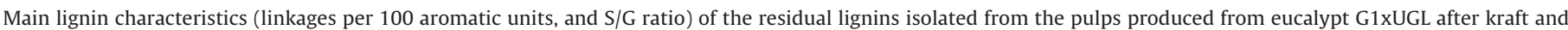
soda-AQ processes at kappa 20 and 15. The composition of the MWL isolated from G1xUGL is shown for comparison.

\begin{tabular}{|c|c|c|c|c|c|}
\hline \multirow[t]{2}{*}{ Linkages (per 100 aromatic units) } & \multirow[t]{2}{*}{ MWL } & \multicolumn{2}{|l|}{ Soda-AQ } & \multicolumn{2}{|l|}{ Kraft } \\
\hline & & Kappa 20 & Kappa 15 & Kappa 20 & Kappa 15 \\
\hline$\beta-0-4$ alkyl-aryl ether & 75.1 & 11.0 & 8.7 & 15.5 & 10.1 \\
\hline$\beta-\beta$ resinols & 13.4 & 7.6 & 6.2 & 6.4 & 5.6 \\
\hline$\beta-5$ phenylcoumarans & 6.2 & 1.5 & 1.4 & 1.1 & 1.0 \\
\hline $\mathrm{S} / \mathrm{G}$ ratio & 2.8 & 2.8 & 2.8 & 3.0 & 3.0 \\
\hline
\end{tabular}

Table 14

Heating value, total solids, inorganic solids, and organic solids of the black liquor obtained by soda-AQ and Kraft processes ending in kappa number 15 and 20.

\begin{tabular}{|c|c|c|c|c|c|c|c|c|c|}
\hline & & \multicolumn{4}{|l|}{ Kappa 15} & \multicolumn{4}{|l|}{ Kappa 20} \\
\hline & & $\begin{array}{l}\text { Heating value } \\
(\mathrm{cal} / \mathrm{g})\end{array}$ & $\begin{array}{l}\text { Total Solids } \\
(\%)\end{array}$ & $\begin{array}{l}\text { Inorganic } \\
\text { Solids (\%) }\end{array}$ & $\begin{array}{l}\text { Organic } \\
\text { Solids (\%) }\end{array}$ & $\begin{array}{l}\text { Heating value } \\
\text { (cal/g) }\end{array}$ & $\begin{array}{l}\text { Total Solids } \\
(\%)\end{array}$ & $\begin{array}{l}\text { Inorganic } \\
\text { Solids (\%) }\end{array}$ & $\begin{array}{l}\text { Organic } \\
\text { Solids (\%) }\end{array}$ \\
\hline \multirow[t]{4}{*}{ Soda-AQ } & U1xU2 & 3442.5 & 13.4 & 45.4 & 54.6 & 4000.2 & 13 & 45.2 & 54.8 \\
\hline & G1xUGL & 3705.1 & 13.5 & 49.7 & 50.3 & 4049.1 & 11.2 & 47.6 & 52.4 \\
\hline & DGxU2 & 3691.3 & 15.7 & 46.9 & 53.1 & 4071.3 & 12.4 & 43.7 & 56.3 \\
\hline & IP & 3602.3 & 13 & 49.8 & 50.2 & 4072.6 & 11.3 & 46.1 & 53.9 \\
\hline \multirow[t]{4}{*}{ Kraft } & U1xU2 & 3963.1 & 13 & 46.5 & 53.5 & 3949.6 & 10.9 & 45.4 & 54.6 \\
\hline & G1xUGL & 3591.7 & 13.4 & 44.1 & 55.9 & 3970.6 & 12.8 & 49.4 & 50.6 \\
\hline & DGxU2 & 3669 & 12.7 & 46.3 & 53.7 & 4028.8 & 11.2 & 41.4 & 53.7 \\
\hline & IP & 3657 & 12.5 & 46.8 & 53.2 & 3920.3 & 11 & 49.4 & 50.6 \\
\hline
\end{tabular}

liquor enormously facilitates its further fractionation into valuable components (Francis et al., 2008).

Chemically, black liquor is a mixture of several basic elements. The results of $\mathrm{Na}, \mathrm{S}, \mathrm{K}, \mathrm{Cl}, \mathrm{SiO}_{2}, \mathrm{C}, \mathrm{H}, \mathrm{O}$ and $\mathrm{N}$ are presented in Table 15 and are expressed in terms of the percentage of the element mass to the total mass of dry solids existing in the liquor. Potassium and chloride are particularly dangerous for their ability to decrease the ash melting point during combustion, thus causing sticky ash problems in recovery boiler systems (Khan et al., 2009). In addition, chlorides are highly corrosive and troublesome for most equipment regardless of metallurgy (Pfromm, 1997). The amounts of $\mathrm{Cl}, \mathrm{SiO}_{2}$, $\mathrm{C}, \mathrm{N}, \mathrm{H}$ and $\mathrm{O}$ contents were very close among the eucalypt black liquors.
Regarding the lignin structure, they were precipitated from the black liquors of eucalypt wood G1xUGL from the soda-AQ and kraft processes, at kappa 20 and kappa 15 , and were also analyzed by 2D-NMR. The quantification of the main inter-unit linkages and lignin units is shown in Table 16. It is clear from the NMR spectra that these precipitated lignin are enriched in $\beta-\beta$ resinol structures, while the other linkages ( $\beta-0-4$ alkyl-aryl ether and $\beta-5$ phenylcoumarans), if present, are in much lower amounts. An increase of the $S / G$ ratio is observed, indicating that S-lignin units, which are predominantly forming $\beta-0-4$ alkyl-aryl ether structures, are preferentially removed from the eucalypt during pulping and are being enriched in the black liquors. It is interesting to notice that the lignin from soda-AQ process is more enriched in S-lignin units 
Table 15

Elemental analyses of the black liquor obtained by soda-AQ and Kraft processes ending in kappa number 15 and 20 .

\begin{tabular}{|c|c|c|c|c|c|c|c|c|c|c|c|c|c|c|c|c|c|c|c|}
\hline \multirow[t]{2}{*}{ Element (\%) } & & \multicolumn{9}{|c|}{ Kappa 15} & \multicolumn{9}{|c|}{ Kappa 20} \\
\hline & & $\mathrm{Na}$ & $\mathrm{SiO}_{2}$ & $\mathrm{Cl}$ & $\mathrm{K}$ & $\mathrm{C}$ & $\mathrm{H}$ & $\mathrm{N}$ & $\mathrm{S}$ & 0 & $\mathrm{Na}$ & $\mathrm{SiO}_{2}$ & $\mathrm{Cl}$ & $\mathrm{K}$ & $\mathrm{C}$ & $\mathrm{H}$ & $\mathrm{N}$ & $\mathrm{S}$ & $\mathrm{O}$ \\
\hline \multirow[t]{4}{*}{ Soda-AQ } & U1xU2 & 18.3 & 1.4 & 0.06 & 0.06 & 40.2 & 3.9 & ND & ND & 35.2 & 14.9 & 1.9 & 0.07 & 0.09 & 44.4 & 4.0 & ND & ND & 34.3 \\
\hline & G1xUGL & 17.8 & 1 & 0.09 & 0.1 & 40.5 & 3.8 & ND & ND & 35 & 15.3 & 0.7 & 0.08 & 0.07 & 44.1 & 4.0 & ND & ND & 34.9 \\
\hline & DGxU2 & 17.8 & 1.4 & 0.07 & 0.06 & 41.9 & 3.8 & ND & ND & 35.4 & 15.6 & 1.7 & 0.07 & 0.06 & 44.4 & 3.9 & ND & ND & 34.5 \\
\hline & IP & 17.9 & 1.2 & 0.08 & 0.09 & 40.4 & 3.9 & 0.1 & ND & 34.7 & 14.7 & 1.5 & 0.76 & 0.08 & 44.4 & 4.0 & 0.1 & ND & 34.7 \\
\hline \multirow[t]{4}{*}{ Kraft } & U1xU2 & 18.1 & 1.6 & 0.08 & 0.08 & 41.1 & 3.7 & 0.1 & 3.5 & 33.7 & 20.7 & 1.3 & 0.07 & 0.08 & 43 & 3.9 & 0.1 & 2.8 & 34.1 \\
\hline & G1xUGL & 17.8 & 1.1 & 0.1 & 0.07 & 39.2 & 3.7 & ND & 4.5 & 34.7 & 17.4 & 1.4 & 0.1 & 0.08 & 42 & 3.8 & 0.1 & 3.6 & 34.7 \\
\hline & DGxU2 & 22.3 & 1.1 & 0.06 & 0.09 & 41.2 & 3.8 & 0.1 & 3.9 & 34.3 & 14.6 & 1.2 & 0.06 & 0.07 & 43 & 3.9 & ND & 3.3 & 34.4 \\
\hline & IP & 20.5 & 1.4 & 0.05 & 0.06 & 40.6 & 3.8 & 0.1 & 3.4 & 34.8 & 17.9 & 1.4 & 0.12 & 0.07 & 44.7 & 4.0 & 0.1 & 2.9 & 34 \\
\hline
\end{tabular}

ND: not detected.

\section{Table 16}

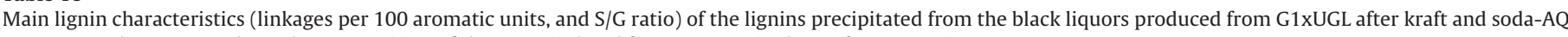
processes at kappa 20 and 15. The composition of the MWL isolated from G1xUGL is shown for comparison.

\begin{tabular}{|c|c|c|c|c|c|}
\hline \multirow[t]{2}{*}{ Linkages (per 100 aromatic units) } & \multirow[t]{2}{*}{ MWL } & \multicolumn{2}{|l|}{ Soda-AQ } & \multicolumn{2}{|l|}{ Kraft } \\
\hline & & Kappa 20 & Kappa 15 & Kappa 20 & Kappa 15 \\
\hline$\beta-0-4$ alkyl-aryl ether & 75.1 & 0.0 & 0.0 & 2.6 & 0.8 \\
\hline$\beta-\beta$ resinols & 13.4 & 2.8 & 4.8 & 6.2 & 6.5 \\
\hline$\beta-5$ phenylcoumarans & 6.2 & 0.0 & 0.0 & 0.6 & 0.0 \\
\hline $\mathrm{S} / \mathrm{G}$ ratio & 2.8 & 8.9 & 12.0 & 6.2 & 6.0 \\
\hline
\end{tabular}

than the lignin from kraft process. In addition, while minor amounts of $\beta-0-4$ alkyl-aryl ether structures are still present in the lignins from kraft process, they were completely absent in the lignin from soda-AQ process. Therefore and as already observed in the analysis of the residual lignins, a comparison between the soda-AQ and kraft processes indicates that the former seems to be more efficient to depolymerize the lignin than the latter.

\section{Conclusions}

- Soda-AQ and Kraft were the most efficient processes for producing pulp.

- The soda-AQ process can potentially replace the kraft one for a high degree of wood delignification (kappa number 15), without significant yield penalty.

- The soda-AQ pulp presented low xylan content in relation to kraft.

- More xylans were retained in kraft and soda-AQ pulps of kappa 20 in relation to kappa 15.

- Xylans from both kraft and soda-AQ pulps are less polydisperse than cellulose.

- The alkaline processes using oxygen (soda-AQ- $\mathrm{O}_{2}$ and soda- $\mathrm{O}_{2}$ ) are more suitable for biofuel production.

- The main linkages observed in the kraft and soda-AQ pulp lignins from G1xUGL eucalypt were $\beta-0-4^{\prime}$ aryl ether, $\beta-\beta^{\prime}$ resinol and $\beta-5^{\prime}$ phenylcoumaran structures.

- The presence of sulphur in kraft black liquor decreases its heating value in relation for soda-AQ black liquor.

\section{Acknowledgments}

Funding provided by the European Community's Seventh Framework Programme FP7/2007-2013 under grant agreement no KBBE-2009-3-244362 LignoDeco, from the Minas Gerais State Research Foundation (FAPEMIG) and from the Brazilian National Council for Science and Technology Development (CNPq) is greatly appreciated. The authors also thank Mr. Paulo Parizzi from the Ministry of Agriculture of Brazil for all support in the materials distribution among the authors.

\section{References}

Alisson, R.W., 1983. Production of bleached softwood pulp by low pollution processes wood. Sci. Technol. 17, 129-137.
Almeida, D.P., Gomide, J.L., 2013. Anthraquinone and surfactant effect on soda pulping. O PAPEL 74 (7), 53-56.

Bracelpa. Associação Dos Fabricantes de Celulose e Papel-Bracelpa. Access on: 22 April, 2013.

Barbosa, L.C.A. Maltha, C.R.A. Cruz, M.P. 2005. Chemical composition of lipophilic and polar extractives of Eucalyptus grandis. Sci. Eng. J. 15 (2), $13-20$.

Björkman, A., 1956. Studies on finely divided wood. Part I. Extraction of lignin with neutral solvents. Sven. Apperstidn. 13, 477-485.

Bose, S.K., Omori, S., Kanungo, D., Francis, R.C., Shin, N.H., 2009. Mechanistic differences between kraft and soda/AQ pulping. Part 1: Results from wood chips and pulps. J. Wood Chem. Technol. 29 (3), 214-226.

Capanema, E.A., Balakshin, M.Y., Kadla, J.F., 2004. A comprehensive approach for quantitative lignin characterization by NMR spectroscopy. J. Agric. Food Chem. $52,1850-1860$.

Cardoso, M., Oliveira, E.D., Passos, M.L., 2009. Chemical composition and physical properties of black liquors and their effects on liquor recovery operation in Brazilian pulp mills. Fuel 88, 756-763.

Chang, V.S., Nagwani, M., Kim, C.-H., Holtzapple, M.T., 2001. Oxidative lime pretreatment of high-lignin biomass. Appl. Biochem. Biotechnol. 94, 1-28.

Chen, Y., Stevens, M.A., Zhu, Y., Holmes, J., Xu, H., 2013. Understanding of alkaline pretreatment parameters for corn stover enzymatic saccharification. Biotechnol. Biofuels 6, 8 .

Colodette, J.L., Gomide, J.L., Longue Júnior, D., Pedrazzi, C., 2007. Effect of pulp delignification degree on fiber line performance and bleaching effluent load. BioResources 2, 223-234.

Cruz, Mariluze, P., et al., 2006. Chemical Characterization of Pitch in Eucalyptus Pulp and Paper Industry, 29. Quím. Nova, São Paulo, June (3).

Dias, V.R.L., Cláudio-Da-Silva Jr., E., 1991. Pulp and paper properties as influence by wood density-same species and age of Eucalyptus. In: International Paper Physics Conference, vol. 1, KailuaKona, Hawai.

Eiras, K.M., Mounteer, A.H., Venturim, G., Colodette, J.L., Gomide, J.L., Acces on: 20/01/2012, available in: http://www.eucalyptus.com.br/icep01/katia eiras2.pdf 2003. Efeito do conteúdo de lignina lixiviável e de ácidos hexenurônicos da polpa na performance da deslignificação com oxigênio. Internationa Coloquiumon Eucalyptus Pulp, 1 pp.

Enayati, A.A., Hamzeh, Y., Mirshokraiei, S.A., Molaii, M., 2009. Papermaking potential of canola stalks. BioRes. 4 (1), 245-256.

Evtuguin, D.V., Neto, C.P., Silva, A.M.S., Domingues, P.M., Amado, F.M.L., Robert D., Faix, O., 2001. Comprehensive study on the chemical structure of dioxane lignin from plantation Eucalyptus globulus wood. J. Agric. Food Chem. 49, 4252-4261.

Foelkel, C., 2007. As fibras dos eucaliptos e as qualidades requeridas na celulose kraft para a fabricação de papel. Eucalyptus Online Book e Newsletter, 48 pp. Available in: http://www.eucalyptus.com.br/capitulos/PT03_fibras.pdf

Foelkel, C.E.B., 1997. Qualidade da madeira de eucalipto para atendimento das exigências do mercado de celulose e papel. In: Conferência IUFRO sobre silvicultura e melhoramento de eucalipto, 1997 Salvador, vol. 1, Anais. Salvador: IUFRO, p. 1.

Francis, R.C., Bose, S.K., Shin, N.-H., Omori, S., Brown, A.F., 2005. Bleached Hardwood Pulps by the Soda/AQ and MAQ Processes. In: 2005 Engineering, Pulping \& Environmental Conference, 2005, Atlanta - GA, USA.

Francis, R.C., Bolton, T.S., Abdoulmoumine, N., Lavrykova, N., Bose, S.K., 2008. Positive and negative aspects of soda/anthraquinone pulping of hardwoods. Bioresource Technol. 99 (17), 8453-8457. 
Francis, R.C., Shin, S.-J., Omori, S., Amidon, T.E., Blain, T.J., 2006. Soda pulping of hardwoods catalyzed by AQ and methyl substituted AQs. J. Wood Chem. Technol. 26 (2), 141-152.

Goldschmid, O., 1971. Ultraviolet spectra. In: Sarkanen, K.V., Ludwig, C.H. (Eds.), Lignins: occurrence, formation, structure and reactions. Wiley-Interscience, New York, pp. 241-266.

Gomes, F.J.B., Gomes, A.F., Colodette, J.L., Gomes, C.M., Souza, E., Macedo, A.M.L. 2008. Influência do teor e da relação $S / G$ da ligninada madeira no desenpenho da polpação Kraft. O Papel (São Paulo) 12, 95-105.

Gomide, J.L., Oliveira, R.C., 1980. Eficiência da antraquinona na polpação alcalina do eucalipto. O Papel, São Paulo 41, 67-72.

Gomide, J.L., Colodette, J.L., Oliveira, R.C., Silva, C.M., 2005. Caracterização tecnológica, para produção de celulose, da nova geração de clones de eucalyptus do Brasil 29. Revista Árvore, Viçosa-MG, pp. 129-137, n.1.

Gomide, J.L., Fantuzzi, N.H., Regazzi, A.J., 2010. Análise de critérios de qualidade da madeira de eucalipto para produção de celulose kraft. Rev. Árvore, Viçosa 34 (April (2))

Guerra, A., Filpponen, I., Lucia, L., Saquing, C., Baumberger, S., Argyropoulos, D.S. 2006. Toward a better understanding of the lignin isolation process from wood. J. Agric. Food Chem. 54, 5939-5947.

Hamzeh, Yahya, Abyaz, A., Niaraki, M.O-S.M., Abdulkhani, A., 2009. Application of surfactants as pulping additives in soda pulping of bagasse. BioResources 4 (4), 1267-1275.

Ibarra, D., Chav́ez, M.I., Rencoret, J., del Río, J.C., Gutierrez, A., Romero, J., Camarero, S., Martinez, M.J., Jimeńez-Barbero, J., Martínez, A.T., 2007. Lignin modification during Eucalyptus globulus kraft pulping followed by totally chlorine free bleaching: A two-dimensional nuclear magnetic resonance, Fourier transform infrared, and pyrolysisgas chromatography/mass spectrometry study. J. Agric. Food Chem. 55 3477-3499.

Karlsson, S., Holmbom, B., Spetz, P., Mustranta, A., Buchert, J., 2001. Reactivity of "Trameteslaccases with fatty and resin acids". Appl. Microbiol. Biotechnol. 55 (3), 317-320.

Khan, A.A., De Jong, W., Jansens, P.J., Spliethoff, H., 2009. Biomass combustion in fluidized bed boilers: potential problems and remedies. Fuel Process. Technol. 90 (1), 21-50.

Khristova, P., Kordsachia, O., Patt, R., Dafaalla, S., 2006a. Alkaline pulping of some eucalypts from Sudan. Bioresource Technol. 97 (March (4)), 535-544.

Khristova, P., Kordsachia, O., Patt, R., Dafaalla, S., 2006b. Alkaline pulping of some eucalypts from Sudan. Bioresource Technol. 97, 535-544.

Kleen, M., Sjöberg, J., Dahlman, O., 2002. The effect of ECF and TCF bleaching on the chemical composition of soda-anthraquinone and kraft pulp surfaces. Nordic Pulp Paper Res. J. 17 (3.).

Labid, J., Tejado, A., García, A., Jiménez, L., 2008. Simulation of tagasaste pulping using soda-anthraquinone. Biores. Technol. 99 (15), 7270-7277.

Lehto, J., Alén, R., 2013. Alkaline pre-treatment of hardwood chips prior to delignification. J. Wood Chem. Technol. 33, 77-91.

Lin, S.Y., Dence, C.W., 1992. Methods in lignin chemistry. Springer-Verlag, Berlin, $578 \mathrm{p}$.

Lindströn, N., Fardim, P., 2012. Chemistry and surface chemistry of vessels in eucalyptus kraft pulps. O Papel 73 (9), 65-72.

Mokfienski, A., Colodette, J.L., Gomide, J.L., Carvalho, A.M.M.L., 2008. Relative importance of wood density and carbohydrate content on pulping yield and product quality. Ciência Florestal 18 (3), 401-413.
Moreira, E., 2006. Efeito da lixiviação ácida de cavacos de eucalipto no processo Kraft Dissertação apresentada à Universidade federal de Viçosa.

Pfromm, P.H., 1997. Low effluent processing in the pulp and paper industry: electrodialysis for continuous selective chloride removal. Sep. Sci. Technol. 32 (18) 2913-2926.

Prinsen, P., Gutiérrez, A., Rencoret, J., Nieto, L., Jiménez-Barbero, J., Burnet, A. Petit-Conil, M., Colodette, J.L., Martínez, A.T., Del Río, J.C., 2012. Morphological characteristics and composition of lipophilic extractives and lignin in Brazilian woods from different eucalypt hybrids. Ind. Crop. Prod. 36, 572-583.

Rencoret, J., Marques, G., Gutiérrez, A., Nieto, L., Santos, J.I., Jiménez-Barbero J., Martínez, A.T., Del Río, J.C., 2009. HSQC-NMR analysisoflignin in woody (Eucalyptus globulusandPiceaabies) andnon-woody (Agave sisalana) ballmilledplantmaterialsatthe gel state. Holzforschung 63, 691-698.

Rencoret, J., Gutieŕrez, A., Nieto, L., Jimeńez-Barbero, J., Faulds, C.B., Kim, H., Ralph, J., Martínez, A.T., del Río, J.C., 2011. Lignin composition and structure in young versus adult Eucalyptus globulus plants. Plant Physiol. 155, 667-682.

Rovio, S., Kuitunen, S., Ohra-Aho, T., Alakurtti, S., Kalliola, A., Tamminen, T., 2011 Lignin oxidation mechanisms under oxygen delignification conditions. Part 2 Advanced methods for the detailed characterization of lignin oxidation mechanisms. Holzforschung 65, 575-585.

Scandinavian Pulp, Paper And Board Testing Committee (1993) Scan Test Methods.

Scott, R.W. 1979. Colorimetric Determination of Hexuronic Acids in Plant Materials. Anal. Chem. 7, 936.

Seth, R.S., Page, D.H., 1988. Fiber properties and tearing resistance. TAPPI J. (February), 103-107.

Seth, R.S., 2003. The measurement and significance of fines. Pulp Paper Canada 47 (2), 104.

Silva Jr., F.G., Do Valle, C.F., Muner, J.C.G., 1996. Programa de qualidade da madeira da Votorantim Celulose e Papel-VCP. O Papel, 35-43.

Solar, R., Kacik, F., Melcer, I., 1987. Simple semimicro method for the determination of O-acetyl groups in wood and related materials. Nordic Pulp Paper Res. J. (4) 139-141.

Standard Methods for the Examination of Water and Wastewater (2000). American Public Health Association, 20 ed. APHA, Washington, pp. 937.

Technical Association of The Pulp And Paper Industry, 2000. TAPPI Standard Methods. TAPPI, Atlanta.

Vakilainen, E., 2000. “Chemical Recovery”. Papermaking Science and Technology 6b. Published in Cooperation with the Finish paper Engineering's Association and TAPPI.

Vishtal, A., Kraslawski, A., 2011. Challenges in industrial pplications of technical lignins. BioResources 6 (3), 3547-3568.

Vuorinen, T., Teleman, A., Fagerström, P., Buchert, J., Tenkanen, M., 1996. Selective hydrolysis of hexenuronic acid groups and its application in ECF and TCF bleaching of kraft pulps. In: International Pulp Bleaching Conference, Washington. Proceedings... Washington, pp. 43-51.

Wallis, A.F.A., Wearne, R.H., Wright, P.J., 1996. Chemical analysis of polysaccharides in plantation eucalypt woods and pulps. AppitaJournal 49 (4), 258-262.

Wehr, T.R., Barrichello, L.E.G., 1993. Cozimentos kraft com madeira de Eucalyptus grandis de diferentes densidades básicas e dimensões de cavacos. In: Congresso Anual Da Abtcp, 25, 1993, São Paulo. ABTCP, Anais São Paulo, pp. 33.

Zong Lai, Y., 1999. The Influence of Alkaline Pulping Conditions on the Efficiency of Oxygen Delignification. Access on: 22 January, 2012. Available in: http://www.TAPPI.org/Downloads/unsorted 